\title{
A Study in Developing a Charger Helmet as Power Bank of Mobile Phone for Motorcyclists
}

\author{
Syifaul Fuada ${ }^{a^{*}}$, Fendy Hananta Pa, Arya Kusumawardhana ${ }^{a}$ and Puji Suharmantob
}

a Jurusan Teknik Elektro Fakultas Teknik, Universitas Negeri Malang, Jawa Timur

b Program Magister Departemen Fisika FMIPA, Universitas Indonesia, DKI Jakarta

\begin{abstract}
Wearing a helmet is one of the obligations to be adhered to motorcyclists. Yet, the existence of helmets is not only as protective gear head but also as a lifestyle even leading to advanced technologies, such as 1) color changing helmet, 2) folding helmets, 3) glowing helmets, and so on. Therefore, the innovation has given a touch on the idea of helmet concepts that is more useful than before and a prototype that has never existed before. This paper describes how the concept of helmet charger is. In fact, the innovation is conceptualized to generate electricity from the helmet, which is a photovoltaic solar cell. The electricity generated can be used for various purposes, like charging a cell phone. Furthermore, the things underlying helmets as a means of placing solar cells is that the body heat of the sun which is quite broad and equitable helmet that will help the solar cells to have an ideal position by facing the sun directly. At the end, the helmet covered by solar cells will have been ready to store electrical energy in batteries as much as 12 VDC. This paper describes a helmet design for the solar power charger and a solar-powered helmet design that can generate voltage as needed.
\end{abstract}

Keywords: charger, electric energy, helm, photovoltaic cells

\section{Introduction}

Inevitably, as the technology todays keeps developing all the time, the need towards electrical energy keeps increasing. For the case, some countries have volunteered to the supply of energy by renewable energy, such as solar, wind, tidal, wave, bioethanol, etc. Besides, that people concerning the technological development work harder in developing the generation of electrical energy levels of consumption of electrical energy rises. For example, 1) the completion of loop system on air conditioner which is to change wasted heat into more usable electricity, 2) power saving technology on television, 3) the innovation on PC technology which makes it getting thinner, 4) Mobile Production Development with the high-tech production, and so on. As age advances, the trivia will happen to be a surprise with its innovations, as what has happened to helmets. Additionally, Helmet is one of driving bike or motorbike outfit for safety purposes. Moreover, helmet is to be worn to anticipate any serious risks which may happen while driving, such as accident. Besides, referring to ISO 1811-2007 any helmets worn by drivers must meet opened and closed helmet standards. Yet, they have to comply with the terms of the construction, design of the morphological aspect, including materials used outside and inside of the helmet. It must be put in a high consideration in producing as well as wearing it because bikers wearing non-standard helmet will damage his brain three times more severe compared to those wearing SNI standard helmet.

On the other hand, cell phones nowadays have become one of main communication tools which people cannot leave without. Due to the reason, it would be bad when the important use of cell phone is obstructed by the battery power that is not long lasting: worse, when the electric source is out of reach. The condition, now then becomes the basic and main reason of bringing forward an innovative idea to design a helmet that can provide benefits to users, especially when traveling. The innovation lies at the capability of the helmet to supply

\footnotetext{
* Corresponding author: Tel: +62 85755136100

E-mail: fsyifaul@gmail.com
} 
power for cell phones since it is designed to be able to recharge itself while it is in use (travelling).

To support the innovation, one of renewable energy source that is potential to be developed is solar energy. Yet, Indonesia with its geographic location that provides high sunlight intensity $(4.8 \mathrm{kWh} / \mathrm{m} 2 /$ days $)$. Thus, the selection of solar energy is the right decision, for it is inexpensive, and renewable as well to be converted from electricity to cell phone power.

\section{Solar Energy Conversion into Electric Energy}

Solar energy is the heat energy derived from the sun's heat through radiation, or better known as a result of the energy intensity of sunlight. Solar energy can be converted into electrical energy using certain equipment. Solar energy has so far been used as source of energy by humans. Solar energy is including in a group of renewable energy as an infinite source of energy that can be used as a source of alternative energy to replace fossil fuels.

Although the use of solar energy has the advantage of not producing waste as the use of other energy sources, but the use of solar energy can be used only during the day so it can be optimal only in a few hours, but it can give a new way to overcome the use of storage (batteries, battery, etc.). In addition, the use of solar energy is influenced by changes in the weather. It is an obstacle to the use of solar energy.

The process of converting solar light into electricity may occur due to the building blocks of a semiconductor solar cells, namely $\mathrm{n}$ and $\mathrm{p}$ type semiconductor. $\mathrm{N}$ type semiconductor is a semiconductor that has an excess of electrons, so that the excess negative charge. While the p-type semiconductor has excess holes, so it excesses positive charge. By adding another element to the semiconductor, we can control the types of semiconductors, such as in Figure 1.

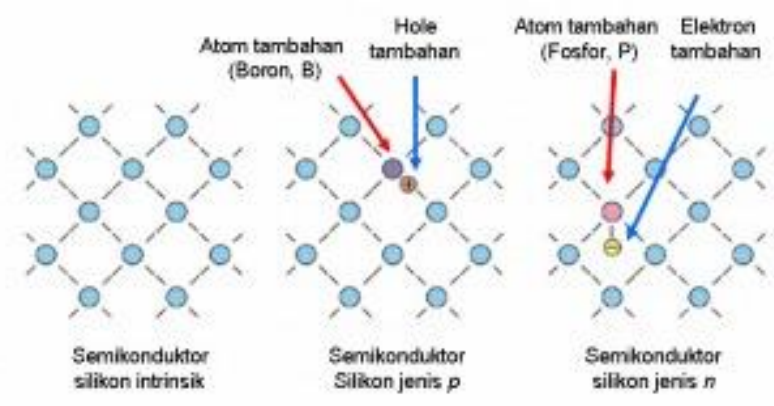

Fig. 1 The addition of elements in semiconductors

P-type semiconductor is usually created by adding boron (B), aluminum (Al), gallium (Ga) or Indium (In) to silicon (Si). These additional elements will increase the number of holes. Whereas, the $\mathrm{n}$ type semiconductor is made by adding nitrogen $(\mathrm{N})$, phosphorus $(\mathrm{P})$ or arsenic (As) into the silicon (Si). Thus, additional electrons can be obtained. This effort adds an additional element called doping amount that is not more than $1 \%$ compared to the weight to be on the Si-doping.

Two types of semiconductor $n$ and $p$ are taken together and they will form a pn junction or a pn diode (another term called the connection metallurgy/metallurgical junction). Shortly after these two types of semiconductors are connected, the displacement of the electrons from the semiconductor to the semiconductor $\mathrm{p} \mathrm{n}$, and hole transfer from the semiconductor to the semiconductor $\mathrm{p} \mathrm{n}$. Displacement of electrons and holes is only up to a certain distance from the boundary of the initial connection.

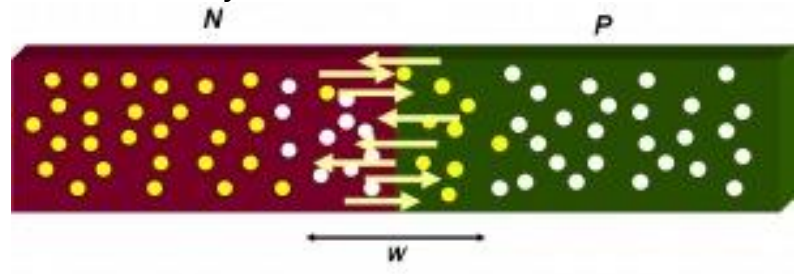

Fig. 2 Transfer of electrons and holes in semiconductor

Electrons from the semiconductor $n$ united with the hole in the semiconductor $\mathrm{p}$ resulting number of holes in the semiconductor $\mathrm{p}$ will be reduced. This area eventually turned out to be more negatively charged. At the same time, the holes of semiconductor $\mathrm{p}$ united with that of the semiconductor electrons resulting $n$ the number of electrons in this region is reduced. This region is more positively charged end. 


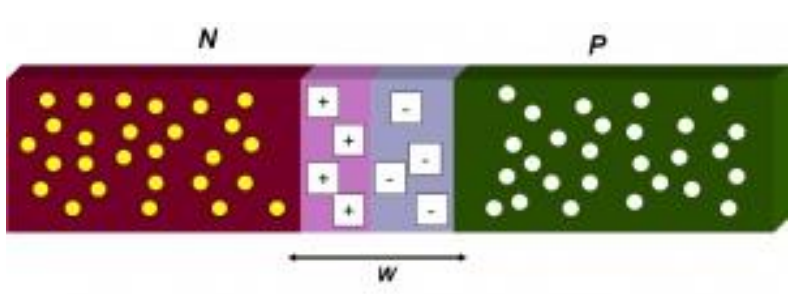

Fig. 3 Depletion region in the semiconductor (w area)

Electrons from the semiconductor $\mathrm{n}$ is united with the hole in the semiconductor $\mathrm{p}$ and it will result $\mathrm{a}$ number of holes in the semiconductor $\mathrm{p}$, then it will be reduced. This area eventually turns out to be more negatively charged. At the same time, the holes of semiconductor $\mathrm{p}$ united with that of the semiconductor electrons resulting $\mathrm{n}$ the number of electrons in this region is reduced. This region is more positively charged end.

Negative and positive region is called the depletion region (depletion region) is marked with the letter $\mathrm{W}$. Electrons or holes that exist in the depletion region is called the minority carriers (minority charge carriers) due to its presence in different types of semiconductors. Differences in positive and negative charges in the depletion region, causing the internal electric field. Presence of an electric field resulting in a pn junction is at the equilibrium point. $\mathrm{E}$ is the electric field prevents the electrons and holes move across from one semiconductor to another semiconductor.

The process of converting solar light into electricity occurs at the pn junction. In the solar cell, semiconductor $\mathrm{n}$ faces the arrival of solar rays and is located in the upper layers of connection p. Semi conductor $\mathrm{n}$ has a thinner layer of the $\mathrm{p}$ layer so that the solar light that falls onto the surface of the solar cells can continue to be absorbed and enter the depletion region and the semiconductor $\mathrm{p}$.

When the connection is exposed to semiconductor solar light, the electrons gain energy from solar light to detach itself from the semiconductor $n$ and the depletion region. The release of electrons leaves holes in the area left by fotogenerasi electrons called electronhole (electron-hole photogeneration), the formation of pairs of electrons and holes due to solar light.

At the pn junction, there is electric field E, so the electrons result fotogeneration gravitate toward semiconductor $\mathrm{n}$, as well as the hole that gravitate toward the semiconductor $\mathrm{p}$.

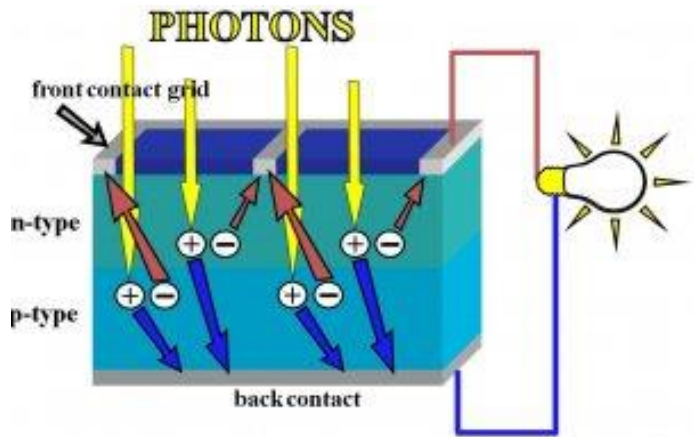

Fig. 4 The process of converting solar energy into electrical energy

The energy released by solar rays actually is only received by the earth's surface by $69 \%$ of the total solar radiant energy. Supply of solar energy from solar rays received by the earth's surface is extraordinary magnitude, reaching $3 \times 10$ joules per year, the energy equivalent of $2 \times 1017$ Watt. The amount of energy is equivalent to 10,000 times the energy consumption in the entire world today. In other words, by covering only $0.1 \%$ of the earth with solar cell devices that have an efficiency of $10 \%$ is able to cover the energy needs around the world today.

In short, the principle is to use solar cells as the particle theory of light. The energy emitted by a light with a wavelength of $\mathrm{V}$ defined by the equation $\mathrm{E}=\mathrm{hc}$ / $\lambda$. With Plancks $h$ is a constant (6.62 $\times 10-34 \mathrm{Js})$ and $\mathrm{c}$ is the speed of light in a vacuum $(3.00 \times 108 \mathrm{~m} / \mathrm{s})$. The above equation also shows that the photon can be viewed as a particle or as a wave of energy with a specific wavelength and frequency. By using a semiconductor device that has a large surface and consists of a series of $\mathrm{p}$ and $\mathrm{n}$ type diodes, the light that comes will be able to be converted into electrical energy.

\section{Corelation the Power with Electric Energy}

Electric Energy is ability for execute or produce electricity (the ability that required for forwarding capacity from 1 dot to other dot. This is electric energy bigness given equation, see number 1 until 3 .

$$
\mathrm{W}=\mathrm{Q} . \mathrm{V}
$$

where :

$\mathrm{W}=$ electric energy (joule),

$\mathrm{Q}=$ electric capacity (coulomb) and

$\mathrm{V}=$ voltage (volt) 
Because $I=Q / t$, so we get equality of:

$$
\mathrm{W}=\text { V.I.t }
$$

when that equality connected with Ohm's law $(V=I . R)$ so we get equality of:

$$
\mathrm{W}=\text { I.R.I.t }
$$

The unit of electric energy that often used is calorie which 1calory is 0,24 Joule besides using $\mathrm{kWh}$ unit (kilowatt jam) also.

\section{Design of Helm Charger}

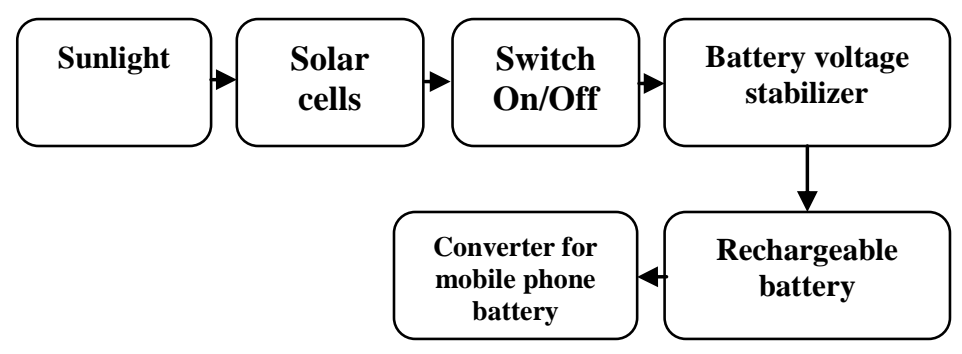

Fig. 5 The flow chart of Prototyping helmet charger

1. Sun as the main source of environmentally friendly energy and the abundant amount.

2. Solar cells as an energy converting sunlight into electricity.

3. Switch on/off as a connector and a power breaker. Used when charging the battery is used or not.

4. 12 Volt voltage stabilizer is used so that the output voltage of the solar cells are not up and down and stick to the 12 Volts.

5. Recharging batteries as energy storage of electricity generated by the solar cells.

6. Stories rechargeable batteries to cell phone batteries, is equipped with a $5 \mathrm{~V}$ voltage stabilizer, voltage stabilizer Given will minimize damage to the cell phone battery .
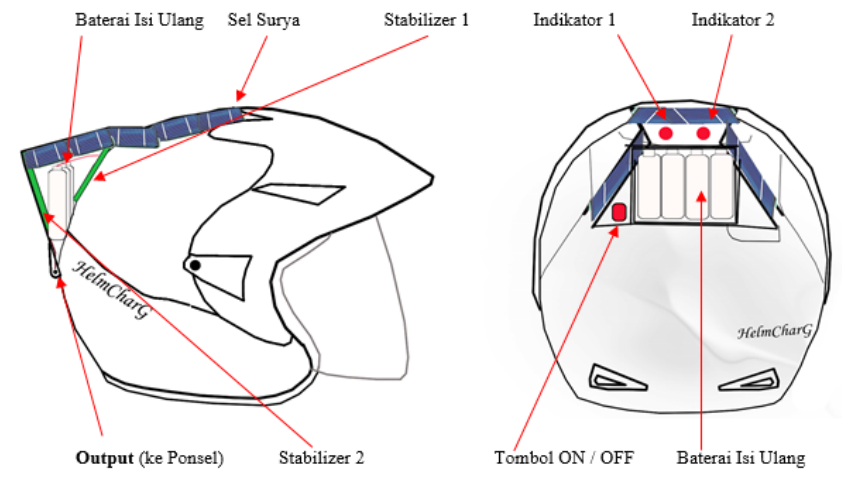

Fig. 6 Desing of prototype the helm charge (2-D)

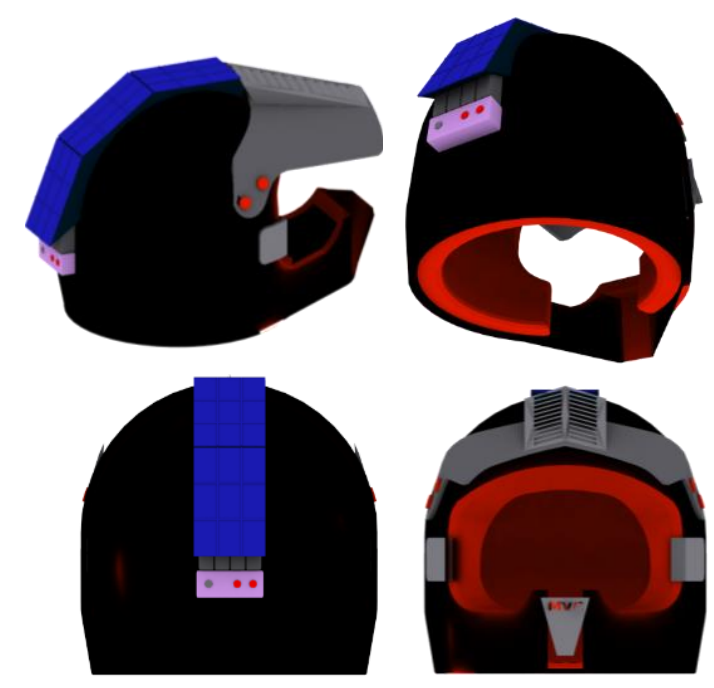

Fig. 7 Desing of prototype the helm charge (3-D)

Installing solar power plants require planning regarding power requirements such as: the amount of usage, the number of solar cells, and the number of batteries. It is adjusted to the needs of the power used while charging, following a manual count of the analysis:

$>$ Calculation needs battery power: $\mathbf{P}=\mathbf{V}$.I

$>$ The mobile requires a supply of 5 Volts and $1000 \mathrm{mAh}$, so $\mathrm{mAH} / 10005 \times 1000$ is $5000 \mathrm{~mW}$ or 5 Watt

$>$ The helmet can be used for mobile phone charger 1 for 1 hour so that the total power requirement is:

5 Watt x 1 hour x 1 = 5 Watt Hour 
$>$ Output of solar cell is 1-2 Volt (when light conditions), so a 1 Volt solar cell consists of about 6 solar cells (to produce a maximum of 12 volts and 6 volts at minimum condition).

$>$ The number of required solar cell is 20 Watt calculated (the calculation is 1 hour solar maximum):

\section{The needs of solar panels / solar cell :} ( 5/20 x 1 hour) must same with 6 solar cell

The needs of minimum battery (only used battery $50 \%$ of electricity needs), thus the power requirement multiplied 2 folding : 5 Watt $\times 2$ is 10 Watt hour is $10 / 2$ Volt/250 mAh battery is 5 battery with $200 \mathrm{mAh}$.

> The power of phone is $1000 \mathrm{mAh}$, so the battery selection is $2 \mathrm{~V} / 200 \mathrm{mAh}$ (because of 5 battery is $5 \times 200 \mathrm{mAh}$ with power battery).

$>$ Size of the solar cell is $3 \times 4 \mathrm{~cm}$, so if it takes 6 solar cells make $3 \times 4 \times 6$ is $72 \mathrm{~cm}^{2}$ solar cell area that surrounds the helmet.

\section{Discussion and Summary}

This paper is introduction project to make helmet cherger using solar energy with photovoltaic cells, so the authors want to give summary for this article: Rapidly evolving technologies make increasingly sophisticated communication tool and has been popular in the community, according to this evidence fit the facts Antaranews.com (2010) that the number of mobile phone users in Indonesia in the year 2010 alone has reached 180 million subscribers, or $80 \%$ of the total population of Indonesia. Talk about energy needs, Indonesia should be on the alert for providing electrical energy to the scale KV (assumption: 180,000,000 x 5V). Therefore in line with the government's program that is $25 / 25$ in 2025 , the author trying hard to participate and assist the efforts of government programs. Specifically in this study the authors make a prototype, which is an environmentally friendly energy supply system as well as practical use by all communities in Indonesia.

The sun is the primary energy source that emits enormous energy to the earth's surface. On the sunny weather conditions, the surface of the earth is about 1000 watts of solar energy per-meter ${ }^{2}$. Less than $30 \%$ of the energy is reflected back to space, $47 \%$ is converted into heat, $23 \%$ is used for the entire circulation of the work contained in the earth's surface, a minority $0.25 \%$ accommodated wind, waves and currents, and there is still a very small part $0.025 \%$ recorded through the process of photosynthesis in plants are finally used in the process of formation of coal and oil (fossil fuels, the process of photosynthesis which takes millions of years) are currently used extensively and exploratory, not only for fuel but also for material for plastic, Formica, other synthetic materials. So it can be said that the source of all energy is solar energy.

The solar cells is used as one of the main ways to be able to convert sunlight into electrical energy. In sunny weather conditions, a solar cell will produce a constant voltage of $0.5 \mathrm{~V}$ to $0.7 \mathrm{~V}$ with a current of about $20 \mathrm{~mA}$ and the amount of energy received will achieve optimal if the solar cell position (perpendicular) to the sun but it also depends on the cell construction solar itself. This means that a solar cell will generate 0.6 $\mathrm{V} \times 20 \mathrm{~mA}$ is $12 \mathrm{~mW}$. If the sun radiates energy onto the surface of the earth or, just imagine the energy produced solar cells have an area on average compared.

The underlying reason for the helmet as a means of placing the solar cell is basically the use of helmets by two-wheeler riders anytime either for long distance travel, medium range or short range. While the hot sun of the helmet body is quite wide and evenly, in this case solar cells have an ideal position when facing the sun directly so that when the helmet is covered with solar cells is sufficient to store electrical energy in the battery is $12 \mathrm{~V} \mathrm{DC}$.

In the early planning of the author of the initial test installation of solar cells, this is done in order to get the data whether it is feasible or not this project is implemented. Here is the data load testing of solar cells with a cell phone. That instrument is: (1)Multimeters, (2) six of Solar cells, (3) power bank as load, (4) cable, tin and solder. The autor test solar cells in under of the sunlight. Then write the data in tables below: 
Table 1

Testing solar cells with loading mobile phone

\begin{tabular}{|c|c|c|c|c|c|c|c|}
\hline \multicolumn{8}{|c|}{ May, 13-2013 } \\
\hline \multicolumn{3}{|c|}{ no-load } & \multicolumn{5}{|c|}{ on-load } \\
\hline Time & $\begin{array}{c}\mathrm{Vi} \\
\text { (V) }\end{array}$ & $\begin{array}{l}\text { Vo } \\
\text { (V) }\end{array}$ & $\begin{array}{c}V i \\
\text { (V) }\end{array}$ & $\begin{array}{l}\text { Vo } \\
\text { (V) }\end{array}$ & $\begin{array}{c}\text { Il } \\
(\mathrm{mA})\end{array}$ & $\begin{array}{c}\text { P (Voxll) } \\
\text { mW }\end{array}$ & Note \\
\hline $07.00 \mathrm{AM}$ & 13,2 & 5,9 & 5,3 & 4 & 6,3 & 25,2 & + \\
\hline $08.00 \mathrm{AM}$ & 6,2 & 5,6 & 4,9 & 3,8 & 1,9 & 7,22 & - \\
\hline $09.00 \mathrm{AM}$ & 14,1 & 5,9 & 5,4 & 4,1 & 13,5 & 55,35 & + \\
\hline $10.00 \mathrm{AM}$ & 13,7 & 5,9 & 5,4 & 4,1 & 11,8 & 48,38 & + \\
\hline $11.00 \mathrm{AM}$ & 13 & 5,9 & 5,3 & 4 & 8,8 & 35,2 & + \\
\hline $00.00 \mathrm{PM}$ & 13,7 & 5,9 & 5,4 & 4,1 & 11,8 & 48,38 & + \\
\hline $01.00 \mathrm{PM}$ & 14,2 & 5,9 & 5,4 & 4,1 & 14,8 & 60,68 & + \\
\hline $02.00 \mathrm{PM}$ & 13,6 & 5,9 & 5,4 & 4,1 & 12,4 & 50,84 & + \\
\hline $03.00 \mathrm{PM}$ & 9 & 5,9 & 5 & 4 & 2,3 & 9,2 & - \\
\hline $04.00 \mathrm{PM}$ & 5 & 4 & 4,6 & 3,8 & 0 & 0 & - \\
\hline $05.00 \mathrm{PM}$ & 2,9 & 0,6 & 0 & 0 & 0 & 0 & - \\
\hline
\end{tabular}

Table 2

Testing solar cells with loading mobile phone

\begin{tabular}{|c|c|c|c|c|c|c|c|}
\hline \multicolumn{8}{|c|}{ May, 14-2013 } \\
\hline \multicolumn{3}{|c|}{ no-load } & \multicolumn{5}{|c|}{ on-load } \\
\hline Time & $\begin{array}{c}\mathrm{Vi} \\
(\mathrm{V})\end{array}$ & $\begin{array}{l}\text { Vo } \\
\text { (V) }\end{array}$ & $\begin{array}{c}\text { Vi } \\
\text { (V) }\end{array}$ & $\begin{array}{l}\text { Vo } \\
\text { (V) }\end{array}$ & $\begin{array}{c}\text { Il } \\
(\mathrm{mA})\end{array}$ & $\begin{array}{c}\mathbf{P} \\
\text { (VoxIl) } \\
\text { mW } \\
\end{array}$ & Note \\
\hline $06.00 \mathrm{AM}$ & 3,1 & 1,3 & 3,1 & 1,3 & 0 & 0 & - \\
\hline $07.00 \mathrm{AM}$ & 11 & 5,9 & 5,2 & 3,9 & 4 & 15,6 & + \\
\hline $08.00 \mathrm{AM}$ & 16 & 6 & 5,5 & 4,1 & 48 & 196,8 & + \\
\hline $09.00 \mathrm{AM}$ & 16,4 & 6 & 5,5 & 4,1 & 68 & 278,8 & + \\
\hline $10.00 \mathrm{AM}$ & 16,6 & 6 & 5,5 & 4,2 & 70 & 294 & + \\
\hline $11.00 \mathrm{AM}$ & 16,3 & 6 & 5,5 & 4,1 & 38,8 & 159,08 & + \\
\hline $00.00 \mathrm{PM}$ & 16,4 & 6 & 5,5 & 4,1 & 49,4 & 202,54 & + \\
\hline $01.00 \mathrm{PM}$ & 16,1 & 6 & 5,5 & 4,1 & 21 & 86,1 & + \\
\hline $02.00 \mathrm{PM}$ & 13 & 6 & 5,4 & 4 & 9,2 & 36,8 & + \\
\hline $03.00 \mathrm{PM}$ & 12,1 & 6 & 5,3 & 3 & 7,2 & 21,6 & + \\
\hline $04.00 \mathrm{PM}$ & 10,3 & 6 & 5,2 & 3,9 & 4 & 15,6 & + \\
\hline $05.00 \mathrm{PM}$ & 4,1 & 3,4 & 3,9 & 2,9 & 0 & 0 & - \\
\hline
\end{tabular}

Note:

Load is power bank that specification $5 \mathrm{v} 3000 \mathrm{mAH}$

+ : Indicator is input lamp, On

- : Indicator is input lamp, Off
Based on the experimental data with a solar cell phone charging as shown in Table 1 and 2 above, so this project is feasible, the authors will be investigated and studied more in depth.

\section{Acknowledgements}

To Drs .Slamet Wibawanto, M.T.chairman of the department of electrical engineering, Faculty of Engineering, State University of Malang ( UM ), then Sujito , ST , MT as mentors for this project, then to DIKTI which has funded in developing this project. Then to all fellow Laboratory of Renewable Energy Department of Physics, State University of Jakarta, Faculty of Mathematics and Science, Physics Renewable Energy Group, State University of Jakarta 2013.

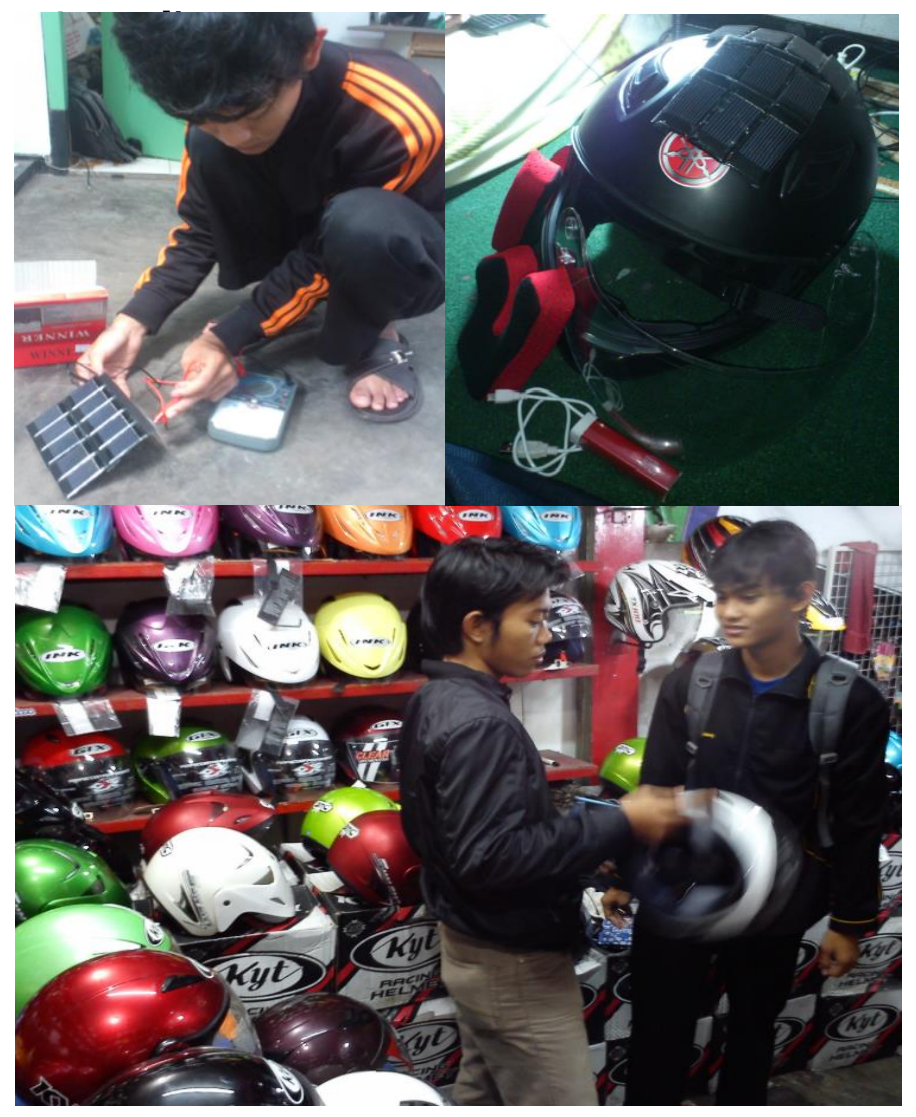




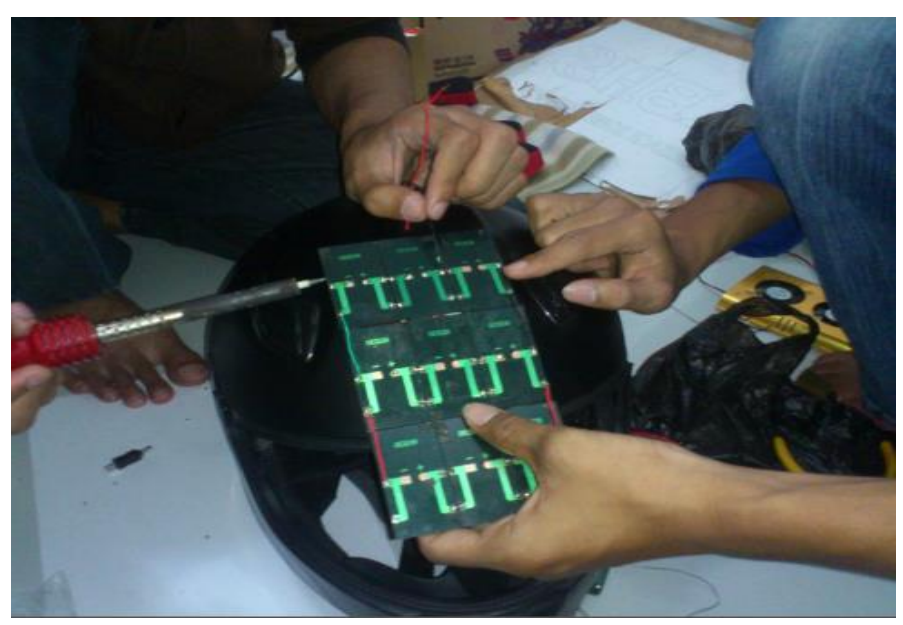

Fig. 8 The helm charger project

\section{References}

Dewi, R. [2012] Pengukuran Arus dan Tegangan Pada Sistem Pembangkit Listrik Hybrid di FMIPA UNJ. Jakarta: Jurusan Fisika Fakultas Matematika dan Ilmu Pengetahuan Alam Universitas Negeri Jakarta.

Dr A Harsono Soepardjo M. Eng Ketua Pusat Studi Kelautan FMIPA-UI dan Peneliti Pusat Studi Energi UI "Energi Baru dan Terbarukan" Kompas 24 Oktober 2005.

Fuad, A. (2011). Application Solar Cells in Daily Life. Paper presented in Workshop Solar Cells at FMIPA, State University of Malang (UM). October, 29-2011

Malvino [1996] Prinsip - Prinsip Elektronika part 2 (translating). Erlangga: Jakarta

Manan, S. [2009] Energi Matahari, Sumber Energi Alternatif Yang Effisien, Handal Dan Ramah Lingkungan Di Indonesia. Available from http://eprints.undip.ac.id/1722/1/solarseeker.pdf

Ramadhani, K. (2009). Pengaruh Hubungan Seri-Paralel Pada Rangkaian Sel Surya Terhadap Efisiensi Konversi Energi Listrik. Prosding TA semester Genap 2008/2009 FMIPA ITS.

R. Alur, T.A. Henzinger, G. Lafferriere, and G.J. Pappas. Discrete abstractions of hybrid

Santhiarsa, I Gusti Ngurah Nitya \& I Gusti Bagus Wijaya Kusuma. (2005). Kajian Energi Surya Untuk Pembangkit Tenaga Listrik. diakses di http://ejournal.unud.ac.id/abstrak/nitya_6_.pdf at September, 5 - 2012

Sasongko, P. [2005] Peranan Konversi Energi dalam penyediaan energi Nasional, Seminar Penghematan Listrik dan Pemanfaatan Energi Alternatif yang terbarukan, Yogyakarta, Systems. Proceedings of the IEEE, 88(7):971-984, July 2000

SNI 1811:2007, About helm for riding. Available from http://www.bsn.go.id/files/321435/20100130/SNI\%2018112007.pdf

Toothman, Jessika \& Scott Aldous [2011] How Solar Cells Work Available from http://science.howstuffworks.com/environmental/energy/solarcell.htm 